\title{
The Integration of Indonesian Culture in BIPA Learning as a Learning Model
}

\author{
A Rofiuddin ${ }^{1}$, G Susanto $^{2}$, P D Anggari ${ }^{3}$, D Ariani ${ }^{4}$ \\ $1,2,3,4$ Universitas Negeri Malang \\ $\{1$ rofiuddin@um.ac.id\}
}

\begin{abstract}
This study aims at developing the learning model that integrates the Indonesian culture in BIPA (Bahasa Indonesia bagi Penutur Asing - Indonesian as a foreign language) learning to meet the needs of BIPA students. The research method used in this study is R2D2 (reflective, recursive, design and development) model by Jerry Willis (2000) [11]. The subjects of the tryout are BIPA students at BIPA Universitas Negeri Malang from ASEAN Countries such as Thailand, Vietnam, Myanmar, and Cambodia who participate in the In-Country Program, Darmasiswa, and $K N B$ Program. The learning model developed has been assessed in the session of tryout. The result shows that the learning model, which is integrating the Indonesian culture for BIPA students are effective to help them to use Indonesian appropriately and accurately.
\end{abstract}

Keywords: Indonesian Culture, BIPA Learning, Learning Model, Lesson Plan

\section{INTRODUCTION}

Learning a language cannot be separated from its' culture. It means that when people are learning a language, subconsciously and consciously they are also learning its culture. As done by foreign students who are learning BIPA, they will also learning Indonesian culture. Some studies investigating the connection between learning languages and culture has been conducted by several second language learning reseachers. A study done by Daniel (2012) who points out that both language and culture are tools for the speakers to express themselves [4]. Therefore, it is clear that language as a means of communication enables people to represent their culture.

Culture plays an essential role in language learning with the purpose of promoting students' communicative competence. As mentioned by Lado (1964 [5] when a language is taught for its educational values, understanding the cultural content associated with the language is important [8]. Language competence and culture are dynamically connected (Rodriques, 2000) [4] as the ability to communicate in a language requires knowledge of seeing, explaining and expressing properly in accordance with the culture (Omaggio \& Hadley, 1986) [7].

In the cultural perspective, BIPA teaching and learning have two interrelated dimensions, namely, introducing Indonesian culture through Indonesian language learning, and learning Indonesian to understand Indonesian culture. This statement is in line with what Susanto (2014) said that learning BIPA is transmitting Indonesian culture [10]. Through BIPA learning, BIPA students know and understand Indonesian culture. Thus, it can be noted that in communicating, it requires an understanding of culture (Stern, 1992) [9].

Based on the explanation above, it is clear that integrating culture in the learning of BIPA seems to be effective to help BIPA students to learn Indonesian. In fact, the learning model used 
so far are not integrating the culture. Besides, the Indonesian language institutions that conducts the BIPA program find difficulties to design learning model to meet the needs of BIPA students. Thus, the present study focuses on the developing of learning model for BIPA students, particularly for the students in the intermediate level.

\section{RESEARCH METHOD}

In developing the learning model for BIPA students, the R2D2 (Reflective, Recursive, Design and Development) model by Jerry Willis (2000) is adapted [11]. There are two important reasons for choosing this model. First, the R2D2 model based on the trend of constructive learning. Constructive learning takes students as the subject of learning, which is very suitable with the character of BIPA students. Second, the R2D2 model involves stakeholders (BIPA teachers and BIPA students) as by involving them who are familiar about BIPA, the products or the learning model can be realized.

To collect the data, the researchers gone through some activities, namely: defining, designing and developing, and dissemination. In the defining step, the researchers created a team where the team consists of seven people. They are divided into four people of research teams and three support teams. The support teams consist of BIPA teachers (two people) and BIPA experts (one person). The next step is designing and developing, the researchers create a design of BIPA learning model that integrates Indonesian culture using Alpha version as the first design and Beta version as the final design of the learning model by firstly validated by the BIPA experts. Then, the revision process was conducted. After the learning model was approved, then, the tryout was conducted to BIPA students who participate in some BIPA programs at Universitas Negeri Malang, in the academic year of 2018/2019 to know the appropriateness of the learning model. At last, in the dissemination session, researchers take an action by sharing the developed learning model to BIPA teachers at a conference and workshop.

\section{RESULTS AND DISCUSSION}

The result of this study is the final version of learning model, which is integrating Indonesian culture in BIPA learning. The final version of developed learning model is called Beta version. It was presented after the revision process. The final product or learning model is in the form of lesson plan, learning scenario, and Indonesian textbook. The book is called "Model-Model Pembelajaran BIPA Bermuatan Budaya Indonesia untuk Pebelajar Tingkat Menengah”. It has several characteristics. They are; it is printed on A4 paper, it contains of 10 learning models where every learning model contains different topics of Indonesian culture, each BIPA learning model is designed for 100 minutes of teaching and learning process, and each model is exposed in 5 to 6 pages containing the authentic text. Next, the book consists of three parts, namely part one, part two and part three. In part one, it consists of four pages (one for cover page, one page of preface, and two pages of table of contents. While in part two, it consists of ten units of lesson plan. This section has fifty-five pages, and part three; it has two pages containing references. Thus, the textbook contains sixty-one pages.

In regard to the topic of Indonesian culture presented in the book are; 1) Aktivitas Seharihari (daily routine activities), 2) Kehidupan Nelayan di Pantai Sendang Biru (Life of fishermen at Sendang Biru Beach), 3) Pasar Tradisonal (traditional market), 4) Permainan Tradisional (traditional games), 5) Legenda Gunung Bromo (the legend of Mount Bromo), 6) Usaha Mikro, Kecil dan Menengah (Micro, Small and Medium Enterprises), 7) Obat Herbal (herbal medicine), 8) Pertunjukkan Wayang Topeng (Mask Puppet Show), 9) Mudik Lebaran (going 
home for Idul al-Fitr), and 10) Laut Masa Depan Orang Indonesia (Sea of the Future of Indonesians). On the other hands, BIPA learning model has a sequence of components as follows; 1) title that is presenting specific cultural topic, 2) the objective of learning, 3) authentic text, 4) learning scenario, and 5) exercises. The description of the text type as the characteristics of the BIPA learning model is presented in the following table.

Table 1. The Texts Type of BIPA Learning Model

\begin{tabular}{llll}
\hline No & Lesson & THEME & GENRE \\
\hline 1 & Lesson 1 & Daily routine activities & Descriptive \\
2 & Lesson 2 & Life of fishermen in Sendang Biru Beach & Descriptive \\
3 & Lesson 3 & Traditional market & Descriptive \\
4 & Lesson 4 & Traditional games & Descriptive \\
5 & Lesson 5 & Legend of Mount Bromo & Narrative \\
6 & Lesson 6 & Micro, Small and Medium Enterprises & Explanation \\
7 & Lesson 7 & Herbal medicine & Procedure \\
8 & Lesson 8 & Mask dance performance & Explanation \\
9 & Lesson 9 & Going home for Idul al-Fitr & Descriptive \\
10 & Lesson 10 & Sea of the future of Indonesians & Exposition \\
\hline
\end{tabular}

The text types mentioned above are well suited for intermediate students. Many BIPA students are interested reading the selected reading texts. By using BIPA learning model, it is found that students improve their language skills and they enable to produce Indonesian properly and accurately. Moreover, the students give positive responses during the teaching and learning process. This finding is in line with the study by Crozet and Liddicoat (1997) [3] that when culture is integrated into language learning, students can learn to speak and write in appropriate ways ([4].

The cultural themes presented in the authentic texts in the learning model were helpful for the students to master the language. It is also found that BIPA students like all of the topics covered in the textbook both in the aspects of linguistic and non-linguistic. The texts were graded based on the students' need as well as the learning objectives. In addition to this, the learning model is also combined with a cultural excursion visit to some places. It is intended to make the students to see and feel, and practice directly the culture written in the textbook. This combination makes the learning of BIPA more effective, fun and enjoyable. Moreover, it enables the students to use language autonomously.

The authentic topic that is presented in BIPA learning model is in line with the development of the communicative approach in language learning. This proves that the role of culture as an interlinked part of language and the necessity of incorporating culture into language learning. Without culture, learning a language is inaccurate and incomplete [4]. Using authentic reading texts provides students with meaningful interactions, in the authentic situations and exposing them in the real context. Therefore, it is necessary to integrate culture so that students know how to encounter their communicative goals (Canale \& Swain, 1980) [2]. According to Brown (2001) [4], students who are exposed to the culture associated with the language have better engagement to themselves in the authentic and functional use of the language for meaningful purposes.

BIPA learning model in this study, when it is analyzed based on a theoretical point of view shows that it is well well arranged. As it is comprising several characteristics of a learning model including; logical theoretical rationales formulated by the theorists, the foundational concepts about what and how students learn, the necessary teaching behaviors essential for the 
success implementation, and the necessary learning environments essential for achieving the learning goals. The learning model also refers to the learning approach used, including the learning objectives and classroom management (Kardi \& Nur, 2000) [4].

Referring to the use of authentic reading texts in this learning model, it also fits with the implementation of content-based instruction (CBI) in foreign language learning. The teacher(s) can create a course of study designed to build their students' interests where the content can be chosen from a number of different topics. This BIPA learning model also based on CBI that contains a variety of authentic reading texts followed by providing vocabularies and comprehension exercises. Thus, it can be said that BIPA learning model is an effective lesson design by combining language and content learning (Davies, 2003) [4].

The BIPA learning model in this study is also approved of $5 \mathrm{C}$ (communication, culture, comparison, connection, and community) principles as suggested by ACTFL [1] to be applied in foreign language learning or in BIPA learning. The $5 \mathrm{C}$ framework well explained in the ACTFL Performance Descriptors such as communication that refers to the ability to convey and receive messages based on three communication models, namely, 1) interpersonal or two-way communication, 2) interpretative or the ability to understand and interpret spoken and written messages, and 3) presentational or the ability to present both spoken and written information. These three models reflect on how people communicate in real life; Culture refers to how language students learn to understand the culture of the target language by studying the cultural products and practices, and how they relate to the mindset of the speakers of the language; how learners develop their ability to access their background knowledge in the field of their study through the target language and to strengthen the concepts that have been learned in their respective field in the language class; Comparison, it relates to the ability of language students to develop insights into their own language and culture by providing a deeper understanding of how language is used and how culture reflects perspectives, practices, and products of speakers who speak the target language; and Community which deals with how language learning becomes more useful and meaningful when students experience outside the classroom [12] [13].

BIPA learning that directs foreign students to be able to use language in real situations is influenced by the principles of sociolinguistic interaction. This principle directs BIPA teaching and learning to use communicative learning models. Hence, it is suggested that learning activities should provide as many opportunities as possible for the students to use Indonesian in real life communication. The selected language material for learning should reflect to the actual speech of the native speakers of the target language in authentic communicative situations, should be in accordance with the use of language used by the native speakers, should be in in line with the expectations of the native speakers and the foreign students regarding the types of language behavior that meets the need of the foreign students, and should aware of various factors in language learning process.

\section{CONCLUSIONS}

The BIPA learning model created in this study integrates Indonesian culture and used as BIPA learning materials. The integration of Indonesian culture in BIPA learning is well organized in the BIPA learning model. It contains ten specific topics, learning objectives, authentic texts, learning scenarios and language production exercises, both oral and written examples of integrating Indonesian culture into BIPA learning and it's application in the classroom. It is also found that this learning model enables students to use Indonesian correctly and appropriately as they have an authentic, appropriate cultural context, and clear as well as real examples of linguistic features (e.g. sentence patterns) from the right linguistic features. 
Besides, the authentic text as the cultural product contains a number of topics that still exists in Indonesia, especially in East Java. In addition, it is in line with the $5 \mathrm{C}$ (communication, culture, comparison, connection, and community) principles as suggested for foreign language learning by ACTFL [1]. Finally, this learning model accommodates various aspect covering (1) integrity, (2) acceptability, and (3) conformity of intermediate students.

\section{REFERENCES}

[1] American Council on Teaching Foreign Language. Performance Descriptors. 2012

[2] M. Canale and M. Swain, "Theoretical bases of communicative approaches to second language teaching and testing". Applied Linguistics, 1(1), 1-47. 1980.

[3] C. Crozet and J.A. Liddicoat, "Teaching culture as an integrated part of language teaching: An introduction". In A. J. Liddicoat \& C. Crozet (Eds.), Teaching language, teaching culture (pp. 1-22). Clayton: Applied Linguistics Association of Australia. 1997.

[4] S. Davies, "Content Based Instruction in EFL Contexts". The Internet TESL Journal, Vol. IX, No. 2. 2003.

[5] R. Lado, Language teaching: A scientific approach. London: McGraw-Hill. 1964.

[6] T. T. Nguyen, Integrating Culture into Language Teaching and Learning: Learner Outcomes. 2017.

[7] C. A. Omaggio and O. A. Hadley, Teaching language in context: Proficiency-oriented instruction. Boston: Heinle \& Heinle. 1986.

[8] V.M. Rodriques, Perspectives of Communication and Communicative Competence. New Delhi: Concept. 2000.

[9] H.H. Stern, Issues and Options in Language Teaching. Oxford: Oxford University Press. 1992.

[10] G. Susanto, "Pembelajaran BIPA sebagai Transmisi Budaya Indonesia kepada Pebelajar Asing”. Prosiding Seminar Internasional IKADBUDI. 2014.

[11] J. Willis, A General Set of Procedures for Constructivist instructional design: The New R2D2 Model. Educational Technology, 40(2), 5-20. 2000.

[12] K. Saddhono, "Integrating Culture in Indonesian Language Learning for Foreign Speakers at Indonesian Universities." J. of Lang. and Lit. vol. 6 no.2 pp. 349-353, 2015

[13] K. Saddhono, "Cultural and social change of foreign students in Indonesia: The influence of Javanese Culture in Teaching Indonesian to Speakers of Other Languages (TISOL)." IOP Conf. Ser.: Ear. and Envi. Sci.. vol. 126 no. 1 IOP Publishing, 2018. 